\title{
Notions of subject and power in Foucaultian readings and their influence in organization and people management studies
}

\author{
Magno Geraldo de Aquino ${ }^{1}$ \\ ${ }^{1}$ Universidade Federal de Minas Gerais (UFMG) / FACULdAde de CIÊNCIAS ECONÔMICAS, \\ Centro de Pesquisa e Pós-Graduação em Administração, Belo Horizonte - MG, Brazil
}

\begin{abstract}
This article reflects on the notion of subject and power characterized by Foucault, considering the three intellectual phases and possibilities of the subject, as portrayed in studies on organizations and management. The research assumes that the ways in which Foucault characterized the subject in intellectual phases reflects the ways the organization manages the individual. In addition, this work highlights the potential of the Foucaultian approach regarding the analysis of subjects and the relations of power in the organizations. In the archaeological phase the proposal is to prioritize the study of organizational discourses. In the genealogy phase, the idea is to advance the analyses of the disciplinary power, relational power, and biopolitics. Finally, in ethics, we suggest the need to analyze the constitution of subjectivities in the work space.
\end{abstract}

Keywords: Foucault. Management. Subject. Power.

Noções de sujeito e poder em leituras foucaultianas e sua influência nos estudos de organizações e gestão de pessoas

\section{Resumo}

O objetivo deste artigo é refletir sobre a noção de sujeito e poder caracterizada por Michel Foucault (1926-1984), considerando suas três fases intelectuais e suas possibilidades nos estudos de organizações e gestão de pessoas. Argumenta-se que os modos como o sujeito foi caracterizado em suas fases intelectuais reflete os modos como o indivíduo fora gerido nas organizações, bem como aponta o potencial que a abordagem foucaultiana oferece para as análises sobre os sujeitos e as relações de poder nas organizações. Na fase arqueológica, propõe-se priorizar o estudo dos discursos organizacionais; na genealogia, argumenta-se sobre a proposta de avançar nas análises do poder disciplinar, poder relacional e biopolítica; na ética, sugere-se a necessidade de analisar a constituição de subjetividades no espaço de trabalho.

Palavras-chave: Foucault. Gestão. Sujeito. Poder.

Nociones de sujeto y poder en lecturas foucaultianas y su influencia en los estudios de organizaciones y gestión de personas

\section{Resumen}

El objetivo de este ensayo es reflexionar sobre la noción de sujeto y poder caracterizados por Foucault, considerando sus tres fases intelectuales y sus posibilidades en los estudios de organizaciones y gestión. Se argumenta que las formas como el sujeto fue caracterizado en sus fases intelectuales refleja los modos como el individuo fue manejado en las organizaciones, así como apunta al potencial que el enfoque foucaultiano ofrece para los análisis sobre los sujetos y las relaciones de poder en las organizaciones. En la fase arqueológica se propone priorizar el estudio de los discursos organizacionales; en la genealogía se argumenta sobre la propuesta de avanzar en los análisis del poder disciplinario, relacional y biopolítico y, en la ética, se sugiere la necesidad de ser analizar la constitución de subjetividades en el espacio de trabajo.

Palabras clave: Foucault. Gestión. Sujeto. Poder. 


\section{INTRODUCTION}

Michel Foucault (1926-1984) concepts have stood out as meaningful for studies and problematization development in several field of studies and thematic. Nevertheless, only in mid-1990s were Foucault thoughts taken as an important set of interpretation for different issues related to the organizational studies fields (BARRATT, 2008; CALDWELL, 2007; CARTER, 2008; KNIGHTS, 2002; MOTTA and ALCADIPANI, 2004). Considerations involving the subject and power are the two themes best related to the studies of Foucault about the organization, with significant reflections while analyzing manners to manage the personnel.

In his intellectual journey, Foucault went through meaningful changes in his interest and research methods (PEREIRA, MUNIZ and LIMA, 2008; STARKEY and HATCHUEL, 2002). That means that his reflections towards power and subject have changed, resulting in a diversity, complexity and heterogeneity of his thoughts, as said by Välikangas and Seeck (2011). Those changes allowed researchers and scholars of Foucault to suggest a division of his concepts into three: archeology, genealogy and aesthetics/ethics. This division is important to obtain an overview of Foucault thoughts and how his concepts may be used in the organization studies (DIXON, 2007) as in personnel management strategies, suggesting the usage of different devices, either discursive or not discursive to be effective (GONÇALVES, 2016). It is a feasible perspective to propose a reflection, in this paper, on a way to refine Foucault analyses. Firstly, about the subject and ordering means of the discursive formation in the 1960s. After, having the subject as an effect of domination and regulation techniques in the 1970s, and lastly the subject as political and ethic agent in the 1980s.

From the notions regarding the man and the forms of control and ordering, we can consider the different manners and techniques of personnel-management in the organizational studies, taking into account the three Foucault intellectual periods. This article deems that the practice of personnel-management is not only illustrative procedures of an organization performance, but also the base of an ideological production. Thus, we cannot distinguish the procedures and the devices, and their discourse about how they work and are lived by the individual. From this, we imply that operational devices and the ideology are permanently connected, having the role to incorporate some behaviors and values that legitimize them.

In support of the concepts of Foucault about the relation between man and his forms of power, we can noticed, in his genealogical period, a drastically change on the focus of a production analysis of the passive subject, typical on the archaeological period, to focus on the manner that individuals establish themselves actively as active subjects. At last, on his ethical period, Foucault focus on the subjects as self-disciplination. On this period, Foucault focus on the analysis of the auto-practices as a manner to connect the subject with the power technologies (MIRANDA, 2014). Although, it is in the intersection of the governmentality notion, developed in his genealogical period, and the reflections about his technology, detailed in the ethics period, that Foucault concepts gain an interesting nuance, while considering the auto establishment of the subject who labors as a management technique.

This paper aims to reflect about the notion of subject and power, developed and characterized by Foucault in his three intellectual periods and his reflection on the studies of organizations and personnel management. When we consider that the foucaultian perspective about the subject and power relations remains little explored, mainly related to the archaeological and ethic periods, this proposal gains consistency. Furthermore, ones argue that the concepts of Foucault, always offer an interesting perspective in the studies related to the organizations and management, considering the social practice an interesting field to be researched.

\section{ABOUT THE SUBJECT AND POWER COGNITION IN FOUCAULT WORKS}

According to Pereira, Muniz and Lima (2008), Dreyfus and Rabinow (2009) and Välikangas and Seeck (2011), Foucault's main works in the archeological period are the following: History of Madness, The Birth of the Clinic, The Order of Things and The Archaeology of Knowledge. During this period, Foucault was interested in studying the "rules of formation" and the "regime of truth" through which the scientific knowledge improves, leading human beings to highlight under particular legitimized discourses (KNIGHTS, 2002). 
During the genealogical period, Foucault published Discipline and Punishment (FOUCAULT, 2014) and The History or Sexuality, Volume 1 (FOUCAULT, 1985). In these works, as mentioned by Knights (2002), Foucault advances in his concepts about the origin of the truth, beginning his reflections about the genealogy of power/knowledge, analyzing the appropriate conditions to have an effective power over the individuals (FOUCAULT, 2004b; SOUZA, 2012). According to Maia (1995), Foucault deeply developed his studies about the relation of power, control over individuals, and the characterization of disciplinary power from 1974 to 1975.

Later on, in 1976, through the work The Will to Knowledge (FOUCAULT, 1985), Foucault introduces a new reflection about power relations, with the concepts of biopower and biopolitics, as governance strategies to have control over life and make living (PEREIRA, MUNIZ and LIMA, 2008), and over the governmentality. The art of governing, at this moment, defines new ideas of ethics and politics (FOUCAULT, 2010c; AVELINO, 2014).

In the late 70s, as said by Villadsen (2014), Foucault turned his attention back to ethics and aesthetics. During this period, the subject is in the center of his reflections development. The main works of this period were the second and third volumes of the History of Sexuality - "The Use of Pleasure" and "The Care of the Self" (FOUCAULT, 1985, 1988); "The ethics of self-care as a practice of liberty" (FOUCAULT, 2004a); "The subject and the power" (FOUCAULT, 2009); and "The hermeneutics of the subject" (FOUCAULT, 2010a). As mentioned by Pereira, Muniz and Lima (2008), Foucault highlighted the role of active and ethics subject and advocated for "the care for the self" and for "the government of itself", simultaneously to the acceptance of individual resources and a way of resistance, making the ways of self-care possible and necessary in the formation of subject as the self.

Foucault (2009) argued the impossibility to study the subjects or the ways human beings are subjects without studying the power relation. According to Foucault (2014) the power is not centralized nor static, but it is broken up into power relations that go above social structures, being nobody able to bypass it (PL ØGER, 2008; RAFFNS $\varnothing$ E, GUDMAND-H $\varnothing$ YER and THANING, 2014; RODRIGUES, 2016). Thus, the reason why the power controls, although not exclusively, and why the individual accepts it, is that the power does not burden on the subject as a not forbidding violence.

Foucault (2012) develops the notions of discursive formation, regimes of truth, and governance technology, as strategies from which the relation knowledge-power are established, in order to demonstrate that power is a network that embraces everyone (GONÇALVES, 2016). In this moment, attention is drawn to the dichotomic process in which the subject experiences his own subjectivation stages: the subject is the one subjugated to the way people see him and the way he sees himself; being the first a given, extrinsic and pre-made image and the latter his self-identity and self-concern (FONSECA, 2014; FOUCAULT, 2010a). Therefore, the individual subjects himself to an image that he did not fully conceived and created. The subject is not a result of a self-constitution, but pushed to become a subject by the standards, established by a regime defined by rules and manner that his society, culture and social group impose (FOUCAULT, 2004a, 2010b).

Although, we cannot see the power only by its downside, but also by its bright side. The power goes deep into our body and causes pleasure (DIXON, 2007), creates knowledge, makes real discourses and makes the emergence and growth of a moral subject possible. In this context, the foucaultian vision suggesting that the power operates but it cannot be priority has meaningful implications in the studies about power relation in the organizations, and the strategies to manage the individual. After all, it is important to trace the analytical space from which is possible to argue that the subject arises from actions that are reflexive and moral responsible, through strategies of self-care, while confronted with specific conflicting situations. These contradictory situations appear when the individual experience a disagreement between the way in which he recognizes himself as subject and the claims imposed in the multiple normative relationship in a space for interaction and social inclusion. Saying that, we must exam through coercitive and self-practice, in an exercise of self-control, the relation between the subject and the games of truth (FOUCAULT, 2004a). A self-control exercise that drives the subject to elaborate, transform, and recognize himself, reaching a certain way of being. 


\section{POWER RELATION IN ORGANIZATIONAL STUDIES AND PERSONNEL MANAGEMENT}

Motta and Alcadipani (2004), aiming to standardize the studies that used the concepts of Foucault about the organization theory, analyzed articles published in the most influential international journals in the field from 1975 to the first half of 2002. The authors pointed out that a major part of the articles analyzed used the concepts of Foucault to discuss themes related to power and the organizations control, prioritizing the notions of disciplinary authority. Motta and Alcadipani (2004) highlight, in addition, that the analyses of the studied articles used the foucaultian perspectives about power in a dissociated way, as if they were instruments that meet the specific argumentation needs, putting aside important contributions given by other foucaultian conceptions of power analytics.

Välikangas and Seeck (2011), in a papers systematization that used the perspective of Foucault in the studies of organization and the way those studies portrayed the subject, between 2000 and 2009, showed similar results to Motta and Alcadipani (2004). They highlighted that most of the articles that analyze organizations and the management process in a foucaultian perspective refer mainly to works from the genealogical period. From this period the concepts of power, more precisely the discipline and surveillance power originated from the concepts developed by Foucault (2014) in his work Discipline and Punishment, are the most cited. In agreement with Motta and Alcadipani (2004) and Välikangas and Seeck (2011), as well as Barratt (2008) we argue that due to his focus in the idea of discipline and surveillance, Foucault contributions for the organizational studies in the archeological and ethic period are commonly neglected.

Knights (2002), claims that Discipline and Punishment, from Foucault, got the scholars of organizations attention because the themes control and surveillance, interpreted into the concepts of institutional view and monitoring, have similarities in the way how employees are controlled at work in contemporaneity. This observation reinforce the perception that a singular reading of Foucault's contributions on the organization analyze, prioritize above all other contributions and proposal of analytic powers (BARRATT, 2008; CRANE, KNIGHTS and STARKEY, 2008; DIXON, 2007; RAFFNS ØE, GUDMANDHØYER and THANING, 2014).

The foucaultian contribution for the understanding of subject and power relations are outlined in the following topics, with the aim of reflecting about the possible interpretation of the organization and management analyses, in the three intellectual period of Foucault.

\section{ARCHEOLOGY, SUBJECT, POWER AND ORGANIZATIONS.}

In the archeological period, Foucault studied psychiatry, medicine, human science and institutional practice speeches (COSTA, GUERRA and LEÃO, 2013). Foucault (2010b), in The Order of Things, observes how classic course; as grammar, political economy and natural history; developed $(\mathrm{SOCIO}, 2016)$, and the reasons why such subjects guarantee that their statements are true while others are false (THIRY-CHERQUES, 2010). His overall project can be defined as a project to analyze how some speeches claim a science status and how they shape the conditions that determine the linguistic, economic and biological formation of the subject (DELEUZE, 2014; FOUCAULT, 2004a, 2014; KNIGHTS, 2002). In this period, the reflections of Foucault about the notions of subject and power strongly connects to the study of discursive practice, and to the manner how some regimes are truly established, according to the historical period (HACK, 2006).

In the foucaultian perspective, we can understand the discourses as rules-based system of classification, regulation, and ordering planning, that establish who is allowed to say something, at a specified moment and manner (CALDWELL, 2007; GIACOMONI and VARGAS, 2010). This rules-based system defines the conditions under which, historically, the subjects are defined and seen, (SILVA and MACHADO JÚNIOR, 2016), at the same time that defines, limits and controls how the same subjects notice themselves and interact with the world (CALDWELL, 2007).

Seen that, while focusing the archeological period of Foucault, we search for a necessary changes on the way that organizational researches are carried out, under the functionalist perspective, that follows the rules and procedures of the positive knowledge (SILVEIRA, 2005), in a structural and qualitative perspective. This allows the development of analyses to understand how to establish the power relations between the organizations and their employees, prioritizing the studies of organizational discourses. 
Bergström and Knights (2006) searched the relation between the organizational discourses and the constitution of subjectivity, during the hiring process of an American company. The authors analyzed through discursive movement, how the candidates speeches begin, support, control, and determine the candidate decision to enter or not in the company as an independent and particular decision. They suggest, as the subjectivity happens during the hiring process the decision depends on the usage and acceptation of the organizational discourses by the candidate as manifestation of their own reasons to work in the company. It is all about understanding that the organization defines, through certain discursive practices, the subjectivity processes without denying that subjectivity is an effect of the permanent interaction, between the human agency and the organizational discourses, not a determination from one to another.

Phillips and Oswick (2012) assert the importance of the organizational discourse analysis as an approach for the studies of organization and administration. In general, it considers the organizational discourse as an important factor to build up an identity at work. For the authors, the organizational discourse provides tools to explore the management process in different settings, while offering a connection between identities and constructs as a manner of control and confidence. The organizations put this into practice through the personnel policy, in order to multiply moments, places and ways to transmit the idea that belonging to certain company is essential as a way to win recognition as a particular worker. This element of ideology begins in the admissions and evaluation interviews, as well as in training periods, company meetings and other ways of internal communications, when the individuals are proud of the company they belong to and appraise its generosity.

The perspective provided by the archeology of Foucault recognizes the management process and the organizational theories as power/knowledge regimes (COSTA, GUERRA and LEÃO, 2013). The organizational theories, in that perspective, are able to identify how an organization and its own organizational practices are seen as accurate (ROSA, 2015), besides the way how workers notice themselves and are described by certain discourses, which still define, the conditions and social practice in the work place. It is possible to claim that, in the studies of organizations and management strategies, the foucauldian reflections have a special contribution in the identification of the discursive process and its formation, as a way to build up a particular area of the legitimated knowledge (COSTA and LEÃO, 2012). This creation is defined based in the arrangement and normativity, what would go beyond the language category and the language regulations in a specific historical and social intersection (ALMEIDA, KEMP and MACHADO, 2014; CANDIOTTO, 2013; FREITAS, 2011; NOGUEIRA, 2006; SILVEIRA, 2005). As pointed by Knights (2002), the archeology of Foucault and the study of the speeches provide variable and interesting possibilities for development of the organizational science (DIXON, 2007) and management studies (PEREIRA, MUNIZ and LIMA, 2008).

While making progress about the articulation among the constituted knowledge, the second foucaultian intellectual period starts focusing in the relation between the doctrines and discoursing places, showing that, in every society, one can control the speech production. Thus, while in the archeology we notice the power mainly as repressive power, in the genealogy the emphasis is in the power coming from the speeches.

\section{GENEALOGY: BEYOND THE DISCIPLINARY POWER IN THE ORGANIZATIONS}

The perspective driven by the foucauldian genealogy makes progress in the analysis of the disciplinary power, allowing analyzing the aspects of the biopolitics and relational power (PEREIRA, MUNIZ and LIMA, 2008). In this regarding, the aim is to redirect the disciplinary process attention to the institutional context in which is the organization. Lastly, Foucault (2010b) engages his reflections regarding the governmentality as a management strategy and tactic to control and lead the behaviors, as a fusion of the domination technics exerted on others and on the self.

The study of different institutions and authorities that establish specific regimes of truth and manners of subjectivity was a key issue in the Foucault genealogical period, especially in the in the volume 1 of The History of Sexuality (FOUCAULT, 1985) and in Discipline and Punishment (FOUCAULT, 2014). In these works, Foucault studied how the discipline, punishment and the sexuality deeply affects the human being. Besides that, he analyzed the way the institutions and authorities use strategies consciously and unconsciously to have power over the subject (KNIGHTS, 2002). 
Foucault (2014), in Discipline and Punishment, while observing the daily life and the social practices, suggests a new research method (VEIGA-NETO, 2009), considering that those have their own regularity, logic, strategy and reason. Considering that at schools, at prisons, at churches and at hospitals, people can show some kind of truth about themselves. We may not take this truth only as a passive force, because it also leads the individuals thought and the self-concept in a particular direction (FOUCAULT, 1985, 2010a). In this perspective, the disciplinary power can be used to transform the person so that to live in the boundaries of the society (FOUCAULT, 2010c), in an organization (CANDIOTTO, 2012) stipulated by the social relations, as a politic practice (COSTA and LEÃO, 2017) in constant activity to manage the daily routine (CARRIERI, 2014).

Inspired by the Discipline and Punishment book (FOUCAULT, 2014), studies about the disciplinary process in the organizations, analyzed the ways they use the surveillance mechanism inspired in the panopticon, as pointed by Motta (1981), Motta and Alcadipani (2004) and Knights (2002) to guarantee an effective self-management by the workers. From the panopticon view, comes a relation of power that enters in the subjectivity of each individual, incorporating in their conscience, function of control, vigilance, and discipline. The individual becomes, in this relation, only follower of the order, not being responsible for his own formation, only for the obedience of the imposed rules. In the panopticon perspective, the human being becomes the tenet of his own subjection (BRÍGIDO, 2013; CARROLL and LEVY, 2010; DANNER, 2017).

The pastoral power is another key possibility to analyze the subject and the power relation of the organizations (PRETES and VIANNA, 2014). Unlike the disciplinary power, that is a manner of influence over each individual, the pastoral power is, essentially, a way of directing bodies and souls with the purpose of obtaining appropriate behaviors (WALTER, WINKLER and CRUBELLATE, 2013). The pastoral power bases on a relation of power, in which the pastor seeks to change the spirit and the desire of the person, and to guide, to lead, to control, and to manipulate, starting from the spiritual orientation through confession. This relation implies that the pastor needs to know more and more about his congregation. The result of the confession practice revels that the individual makes up a particular kind of truth of himself and comes up with a truth that connects him to the one who leads his awareness (CANDIOTTO, 2008; FERREIRINHA and RAITZ, 2010; WALTER, WINKLER and CRUBELLATE, 2013).

In the view of the genealogy of Foucault, the study of the organizations can become analyses about the organizational places. Focusing in the social practices in the relations between managers and subordinates, as well as in the relation between the individual and the work place, as a conceptual space and its geographic dimensions, and about the subject dimension and the working time. As said by Välikangas and Seeck (2011), we must know and analyze all of these dimensions previously their management. These are areas and fields of practical activities that legitimize the knowledge and the truth, and are qualified by specialists and authorities, according to their preeminent hierarchical position. Those are also fields in which ones build strategies of control, developing a calculable individual idea, managing it by calculations (ARAÚJO, 2017).

In the genealogical perspective, Oliveira (2016) reflected on how résumé revels itself as a discursive instrument of the power, reflected in the behaviors used in educational institutions, and on the manner how the educational system pressures the candidates to incorporate the rules, the educational planning, and the syllabus, as well as reflection on the self-discipline. These ideas, in agreement with the genealogical comprehension by Foucault about the subject, propose that we do not control the subject only by external powers because this power is also often an inner pressure. Secondly, these ideas suggest that the subjects are not just passive parts in this power relation field, but active ones.

In governmentality, Foucault aims to comprehend the creation of the government and their purpose (FOUCAULT and SENELLART, 2008). He focus his investigation in the analysis of the emergence of the controlled society, in which the power is scattered among many spokespeople and social institutions. Foucault (2008), in his reflections, considered the uprising of the governmentality and the biopolitics idea. This term, coined to refer to the practices of the Modern State (VEIGA-NETO, 2005), that defines the power relation on the economy and on the population as specie (FONSECA, 2014). The biopolitics operates through the reality of the human beings as living beings, orienting, regulating and leading the individuals (DANNER, 2017) from a certain distance, focusing clearly in the community level (SOUZA, JUNQUILHO, MACHADO et al., 2006; SOUZA, 2012), with the purpose to promote life. The biopolitics is a process of government and regulation of individuals, not anymore from disciplinary and restrictive strategies that address the physical body, but from the body as political place itself (AVELINO, 2014). 
The reflections about the govenmentality enable the analysis of the human interaction process and the conditions of the interaction between the government of the conduct and the way that those allow people to be active, at the same time as exposed to their own exploration. The govenmentality promotes a better perception about the procedures to manage people (FOUCAULT, 2010c), acting and investing increasingly in the instrumentalisation of the individual inclination for selfregulations, aligning those, to socialpolitical purpose (SKINNER, 2013). Sørensen and Villadsen (2015), from the govenmentality perspective, analyze how a management practice, supposedly "non-hierarchical" and aestheticized, reset the relations of power in an organization. The authors imply that the manager uses the ethics operation tactically to shape the company workers behavior, with an important influence in the establishment of the subjectivity. Therefore, Dixon (2007) did not only consider the questions about the domination and the government techniques, but also the techniques of the self.

The freedom proposed in the govenmentality allows the subject to perceive himself fully responsible for his career in the organization, as inferred by Cappelle and Melo (2010), in studies about women police officers graduation. Although, the career is a way that the company sees the workers, allowing, yet, the building of a stable bureaucratic virtue (MCKINLAY, CARTER and PEZET, 2012). The career requires that the company implement a tasks measurement system, establish a clear path in the job ladder, provide a record file to measure personal performance and progression, and develop strategies to evaluate the performance and the worker path regarding the population (MCKINLAY CARTER and PEZET, 2012) and/or the group, in the long term. Seeing that, the company cannot keep the dada about the employees private, but gathered and permanently saved to be analyzed if necessary as the time goes by. Those dada can establish a population and the team rules, and be a tool used by the individual to give him the impression that he knows the issues related to him and have the control about his life in the work place.

Thus, we consider two different basic dimensions of the power: the knowledge and the subjectivity. The first considered as source of individuality and productivity dada, stemming from the power relation. The second, provided by the way of freedom arising from the subject awareness about the power mechanism. In the organizations, we can analyze the dimensions related to ethic issues.

\section{ETHIC, SUBJECT AND RESISTENCE IN THE ORGANIZATIONAL ANALYZES}

In the ethic/aesthetic period, Foucault (2004a) interested in examining how possible can the individuals minimize the domination effects and reach some freedom in different regimes of power (FOUCAULT, 2010c). The concept of technology of the self, shows that the individuals are able to transform themselves in terms of power relation (Foucault, 2004b). This perspective, from the standpoint of Foucault (2010a, 2010c), consists in taking into account that the power relations are only possible inasmuch as the subjects are free. It is possible yet to relate the issue of the resistance growth, to the power gained by a subject in the power relation (FOUCAULT, 2010c). Connected to this idea is the emphasis of Foucault about the power as a primarily from a relational nature.

The Technologies of self are possible manners to transform the human beings into subjects. This is a form of power that applies to the individual daily life, while highlighting their own individuality bequeathing their own identity. From the establishment of a truth that the individual has to auto recognize and take others to recognize themselves. It points out the double meaning for the term subject: subject submitted to another subject, by forms of control and dependence; and the subject submitted to its self-identity, by the conscience of self. In both meanings, the subject reflects a form of power that subjugates and subordinates, as mentioned by Dreyfus and Rabinow (2009).

While the technology of power determines the way to lead the individual and how to guide them to certain purpose and forms of objectification (FOUCAULT, 2010c), as technology of self

[...] permit individuals to perform by their own means, or with the help of others, a certain number of operation on their own bodies and souls, thoughts, conduct, and way of being, so as to transform themselves in order to attain a certain state of happiness, purity, wisdom, perfection and immortality (FOUCAULT, 2004b, p. 323-324). 
The technologies of the self, are directly involved to the capacity of the individuals to shape themselves, assisted by practice of the self-government. Such practices help the individuals to resist the existing forms of domination and discipline (GRABOIS, 2011).

According to foucauldian reflections, it is necessary, in the organizations, to examine the ethics in a practical way, in order to comprehend what managers and workers really do in their daily tasks (STARKEY and HATCHUEL, 2002). It is not about saying that the subject is a result of a symbolic system (MCKINLAY CARTER and PEZET, 2012); but about comprehending that the subject is a creation of real social practices; practices historically analyzable (CANDIOTTO, 2013).

We cannot try to find ideal values taken by the individuals, based on their actions, analyzing the ethic formation of the subject, but by emphasizing that the ethic subjectivity comes from daily actions in real settings (GALVÃO, 2014). Crane, Knights and Starkey (2008), adopted this perspective about the ethic subject formation from the intersection between the forms of control and the technology of the self, and Skinner (2013) adopted the subject self-training process in the organic farming; seeking to analyze the work performance of each individual, not the performance of the team they take part. From this perspective we can comprehend the subject formation in a self-government, while understanding the issues about the emotion (DIXON, 2007), the autonomy formation (MARTIN, LESLIE, MINION et al., 2013), and liberty.

Barratt (2008) gives emphasis in the power relation that the autonomy, in the normative non-dogmatic perspective, would be able to optimize room for the self-government and self-care. This effectively involves an active and continued role of the subject to negotiate fairer proceeding rules in decisions-make loop. However, it is important to give attention to the active engagement of the subject in the goals setting and organizational arrangements and the establishment of power relation boundaries in the work place, establishing a basic domination. Even if it is not possible to extinguish the oppressive regime, the modern configuration of power relation becomes more limited, or less massive, as the human subject becomes author of his own live. This enable us to reflect on self-government and self-care issues, noticed in the power relation in the work place, in its ethic-politic dimension, as coextensive in the social action field.

We cannot deny though, that the power relation in the companies limits the subject possibility to have control of his own life. As a result, the autonomy in the work place, as said, restricts and enforces some responsibilities in the production as an autonomy form (MELO, FREITAS, SIEBRA et al., 2016). Consequently, it hampers the autonomy growth, what makes the work place great for the emergency of the self-government and self-care of an ethic subject.

Therefore, from the aesthetic/ethic period of Foucault, we consider the studies of the organization and management promising, especially if combined with the reflection of the governmentality notion. In the mentioned studies, is possible to exam how the organizations picture the subject, in his subjectivity (CAPPELLE and MELO, 2010; SOUZA, JUNQUILHO, MACHADO et al., 2006), and the relation between power dynamic and resistance (FLEMING and SPICER, 2007), and the fact that different companies have different regulations.

Tedesco and Rodrigues (2012), Grabois (2013), and Skinner (2013) give interesting examples of how we can combine the govenmentality studies with Foucault ethic works. Those authors refer to the four aspects described by Foucault (1988) in the work "The Use of Pleasure", as ethics components (CANDIOTTO, 2013; DÍAZ, 2012): ethical substance, the mode of subjection manners, forms to elaborate ethical work, and the theology of the moral subject. Analyzing ethics, one can emphasize the behavior aspects considered important components of moral conduct. Subjection forms refer to the way the individuals subject themselves to determination and structure regulations, what means a reflection about the forms how the individuals set relationship with rules, regulations, obligations, and ethics standards. The third component, forms to elaborate ethical work, refers to the attitudes and personal habits concerned about the self, behaving according to the established rules. These considerations bring not only the knowledge individuals have about themselves, and how they convert to moral subject of their own behavior through the practice of the self, but also the theology of the subject that reflects in the actions taken by the constituted moral subject. These components focus on the moral subject characterization, not only related to the actions in accordance with values and external rules, but also related, mainly, to a particular characterization. 


\section{FINAL CONSIDERATIONS AND POSSIBLE FUTURE RESERCHES}

In accordance with the addressed perspective, we can consider that the concepts of Foucault in his three periods, about subject and power relations, have important different dimensions that induce, in different forms, the development of organizations surveys. In archeological writings, the idea of subject and subjectivity was little developed. In this period, Foucault did not refer to the subject or to a subjective place. There is only an idea of the possibilities the individual have to say something, or about whom he can say it. However, the subject is in a social context that determines what he can say, at what moment, in which way and by which individual.

Saying that, carrying out researches that analyze the organizational discourses (PEREIRA, MUNIZ and LIMA, 2008) have potential to adopt the foucaultian ideas developed in that period. Therefore, the knowledge would become the focus of the study, to comprehend how the articulation of the knowledge in the organizations can be a base for the development of management strategies. The related proposition essentially consist in the power relation established among employees inside the company that promotes certain visibility from the knowledge position. The contribution comes from the biopolitics strategy, which highlights the necessary knowledge to control the personnel, as a government art. In this perspective, is important to analyze the role the individual plays in the organizational discourse (BRANCA SÓLIO, 2008), since it coordinates the elements of the govenmentality. On the other hand, the govenmentality strategies can point the technology development what may be a result of the power relations and the variations between knowledges, in the ethics subject formation.

Researches to develop historical longitudinal analyses are interesting proposals. This perspective allows us to consider changes in the work conditions and their reflection in the way individuals see themselves in the organization. Historical analyses are necessary to understand why organization and organizational practices are unique. We can study the organizations as locus of specific knowledge and articulated knowledge production, which elaborate discourses on articulated power over the subject.

On the other hand, the comprehension of the continuous self-care effort, that grows in the subject while in the work place, as a form of self-agreement and self-training, put in evidence the problematization heterogeneity, change, and development of particular and collective experiences, established in the power relation. This proposal allows the reflection about the desired and intentionally growth, characteristic of an active subject, as essential in the self-establishment process as an ethics subject, developed in the gap between the resistance and liberty, never as a subject as the ones portrayed in history (FISCHER, 1999).

In this context, for better comprehension of the ethic subject constitution process, in the organizations, is necessary empiric studies to measure effectively the relation between subject and power. Studies about the organizations, from the foucaultian ideas, eventually emphasize the existence of a connection between some organizational practices and the way in which human beings see themselves as subjects, also formed in the organizational discourse. Therefore, it is necessary genealogic studies as well as studies based in the ethics perspective, in order to comprehend the subject constitution in the work place. 


\section{REFERENCES}

ALMEIDA, C. T.; KEMP, V. H.; MACHADO, M. N. M. Sujeito, poder e discurso nas organizações: análise de falas de empresários. Revista Direito Mackenzie, v. 7, n. 1, p. 56-70, 2014.

ARAÚJO, I. L. Foucault, para além de "Vigiar e punir". Revista de Filosofia Aurora, v. 21, n. 28, p. 39-58, 2017.

AVELINO, N. Sujeito a política: tecnologia confessional e controle da subjetividade. In: AVELINO, N.; VACCARO, S. (Orgs.). Governamentalidade/Segurança. São Paulo: Imtermeios, 2014. p. 309-342.

BARRATT, E. The later Foucault in organization and management studies. Human Relations, v. 61, n. 4, p. 515-537, 2008.

BERGSTRÖM, O.; KNIGHTS, D. Organizational discourse and subjectivity: subjectification during processes of recruitment. Human Relations, v. 59, n. 3, p. 351-377, 2006.

BRANCA SÓLIO, M. Comunicação e poder nas organizações. Em Questão, v. 14, n. 2, p. 207-222, 2008.

BRÍGIDO, E. I. Michel Foucault: uma análise do poder. Revista de Direito Econômico e Socioambiental, v. 4, n. 1, p. 56-75, 2013.

CALDWELL, R. Agency and change: re-evaluating Foucault's legacy, Organization, v. 14, n. 6, p. 769-792, 2007.

CANDIOTTO, C. Governo e direção de consciência em Foucault. Natureza Humana, v. 10, n. 2, p. 89-113, 2008.

CANDIOTTO, C. Discipline and security in Michel Foucault: normalization and regulation of delinquency. Psicologia \& Sociedade, v. 24, n. esp., p. 18-24, 2012.

CANDIOTTO, C. A genealogia da ética de Michel Foucault. Educação e Filosofia, v. 27, n. 53, p. 217-234, 2013.

CAPPELLE, M. C. A.; MELO, M. C. O. L. Mulheres policiais, relações de poder e de gênero na Polícia Militar de Minas Gerais. Revista Administração Mackenzie, v. 11, n. 3, p. 71-99, 2010.

CARRIERI, A. P. As gestões e as sociedades. Farol: Revista de Estudos Organizacionais e Sociedade, v. 1, n. 1, p. 19-57, 2014.

CARROLL, B.; LEVY, L. Leadership development as identity construction. Management Communication Quarterly, v. 24, n. 2, p. 211-231, 2010.

CARTER, C. A curiously British story: Foucault goes to business school. International Studies of Management and Organization, v. 38, n. 1, p. 13-29, 2008.

COSTA, F. Z. N.; GUERRA, J. R. F.; LEÃO, A. L. M. S. O solo epistemológico de Michel Foucault: possibilidades de pesquisa no campo da administração. Revista de Ciências da Administração, v. 15, n. 35, p. 168-179, 2013.

COSTA, F. Z. N.; LEÃO, A. L. M. S. Formações discursivas de uma marca global num contexto local: um estudo inspirado no método arqueológico de Michel Foucault. Organizações \& Sociedade, v. 19, n. 62, p. 453-469, 2012.

COSTA, F. Z. N.; LEÃO, A. L. M. S. Dispositivo de Potterheads: organização pautada na ordem do cânone. Revista de Administração Contemporânea, v. 21, n. 4, p. 500-523, 2017.
CRANE, A.; KNIGHTS, D.; STARKEY, K. The conditions of our freedom: Foucault, organization, and ethics. Business Ethics Quarterly, v. 18, n. 3, 2008.

DANNER, F. O sentido da biopolítica em Michel Foucault. Revista Estudos Filosóficos, n. 4, p. 143-157, 2017.

DELEUZE, G. El poder: curso sobre Foucault [1986]. Buenos Aires: Cactus, 2014.

DÍAZ, E. A filosofia de Michel Foucault. São Paulo: UNESP, 2012.

DIXON, M. A. Transforming power: expanding the inheritance of Michel Foucault in organizational studies. Management Communication Quarterly, v. 20, n. 3, p. 283-296, 2007.

DREYFUS, H. L.; RABINOW, P. Michel Foucault: uma trajetória filosófica. Para além do estruturalismo e da hermenêutica. 2. ed. Rio de Janeiro: Forense Universitária, 2009.

FERREIRINHA, I. M. N.; RAITZ, T. R. As relações de poder em Michel Foucault: reflexões teóricas. Revista de Administração Pública, Rio de Janeiro, v. 44, n. 2, p. 367-383, 2010.

FISCHER, R. M. B. Foucault e o desejável conhecimento do sujeito. Educação \& Realidade, v. 24, n. 1, p. 39-59, 1999.

FLEMING, P.; SPICER, A. Contesting the corporation: struggle, power and resistance in organizations. New York: Cambridge University Press, 2007.

FONSECA, M. A. Michel Foucault e a constituição do sujeito. São Paulo: Educ, 2014.

FOUCAULT, M. História da sexualidade. A vontade de saber. Rio de Janeiro: Graal, 1985. v. 1.

FOUCAULT, M. A história da sexualidade. Rio de Janeiro: Graal, 1988. v. 3.

FOUCAULT, M. A ética do cuidado de si como prática da liberdade. In: FOUCAULT, M. Ditos \& escritos: ética, sexualidade, política. Rio de Janeiro: Forense Universitária, 2004a. v. 5.

FOUCAULT, M. Tecnologias de si, 1982. Verve: Revista Semestral Autogestionária do Nu-Sol, n. 6, p. 321-360, 2004b.

FOUCAULT, M. Nascimento da biopolítica: curso dado no Collège de France (1977-1978). São Paulo: Martins Fontes, 2008.

FOUCAULT, M. O sujeito e o poder. In: DREYFUS, H. L.; RABINOW, P. Michel Foucault: uma trajetória filosófica. Para além do estruturalismo e da hermenêutica. 2. ed. Rio de Janeiro: Forense Universitária, 2009. p. 231-249.

FOUCAULT, M. A hermenêutica do sujeito. São Paulo: Martins Fontes, 2010a.

FOUCAULT, M. As palavras e as coisas: uma arqueologia das ciências humanas. São Paulo: Martins Fontes, 2010b.

FOUCAULT, M. O governo de si e dos outros. São Paulo: Martins Fontes, 2010c.

FOUCAULT, M. A arqueologia do saber. Rio de Janeiro: Forense Universitária, 2012. 
FOUCAULT, M. Vigiar e punir. São Paulo: Leya, 2014.

FOUCAULT, M.; SENELLART, M. Segurança, território, população (1977-1978). São Paulo: Martins Fontes, 2008.

FREITAS, E. C. Cultura, linguagem e trabalho: comunicação e discurso nas organizações. Revista Desenredo, v. 7, n. 1, p. 104-126, 2011.

GALVÃO, B. A. A ética em Michel Foucault: do cuidado de si à estética da existência. Intuitio, v. 7, n. 1, p. 157-168, 2014.

GIACOMONI, M. P.; VARGAS, A. Z. Foucault, a arqueologia do saber e a formação discursiva. Revista Veredas, v. 14, n. 2, p. 119-129, 2010.

GONÇALVES, J. F. G. Foucault e a questão do dispositivo, da governamentalidade e da subjetivação: mapeando noções. Revista Margens Interdisciplinar, v. 6, n. 7, p. 105-122, 2016.

GRABOIS, P. F. Resistência e revolução no pensamento de Miche Foucault: contracondutas, sublevações e lutas. Cadernos de Ética e Filosofia Política, v. 19, n. 1, p. 7-27, 2011.

GRABOIS, P. F. Práticas éticas de subjetivação e resistência política em Michel Foucault. Ecos: Estudos Contemporâneos da Subjetividade, v. 3 , n. 1, p. 72-87, 2013.

HACK, R. F. Michel Foucault e a individuação discursiva. Tempo da Ciência, v. 13, n. 26, p. 25-38, 2006.

KNIGHTS, D. Writing organizational analysis into Foucault. Organization, v. 9, n. 4, p. 575-593, 2002.

MAIA, A. C. Sobre a analítica do poder de Foucault. Tempo Social: Revista de Sociologia da USP, v. 7, n. 1-2, p. 83-103, 1995.

MARTIN, G. P. et al. Between surveillance and subjectification Professionals and the governance of quality and patient safety in English hospitals. Social Science \& Medicine, v. 99, n. 3, p. 80-88, 2013.

MCKINLAY, A.; CARTER, C.; PEZET, E. Governmentality, power and organization. Management \& Organizational History, v. 7, n. 1, p. 3-15, 2012.

MELO, A. K. S. et al. A autonomia no âmbito da política nacional de promoção de saúde. Revista Brasileira em Promoção da Saúde, v. 29, n. 4, p. 585-594, 2016

MIRANDA, W. S. Foucault e a questão do sujeito: as tecnologias do eu e a criação de novas subjetividades. Fenomenologia e Psicologia, v. 2 , n. 1 , p. $19-34,2014$

MOTTA, F. C. P. O poder disciplinar nas organizações formais. Revista de Administração de Empresas, v. 21, n. 4, p. 33-41, 1981.

MOTTA, F. P.; ALCADIPANI, R. O pensamento de Michel Foucault na teoria das organizações. Revista de Administração, v. 39, n. 2, p. 117-128, 2004

NOGUEIRA, M. C. O. C. Os discursos das mulheres em posições de poder. Cadernos de Psicologia Social do Trabalho, v. 9, n. 2, p. 57-72, 2006.

OLIVEIRA, J. C. Conhecimento, currículo e poder: um diálogo com Michel Foucault. Revista Espaço Pedagógico, v. 23, n. 2, p. 390-405, 2016.

PEREIRA, M.; MUNIZ, M.; LIMA, J. Foucault e estudos organizacionais: ampliando as possibilidades de análise. Revista de Ciências da Administração, v. 9, n. 17, p. 93-110, 2008.
PHILLIPS, N.; OSWICK, C. Organizational discourse: domains, debates, and directions. Academy of Management Annals, v. 6, n. 1, p. 435481, 2012.

PL $\varnothing \mathrm{GER}$, J. Foucault's dispositif and the city. Planning Theory, v. 7 , n. 1, p. 51-70, 2008.

PRETES, E.; VIANNA, T. Do pastorado ao governo (bio)político dos homens: notas sobre uma genealogia da governamentalidade. Revista EPOS, v. 5, n. 1, p. 131-156, 2014.

RAFFNS $\varnothing E$, S.; GUDMAND-H $\varnothing Y E R$, M.; THANING, M. S. Foucault's dispositive: the perspicacity of dispositive analytics in organizational research. Organization, v. 1, n. 17, p. 1-27, 2014.

RODRIGUES, H. B. C. Ensaios sobre Michel Foucault no Brasil: presença, efeitos, ressonâncias. Rio de Janeiro: Lamparina, 2016.

ROSA, E. C. Teoria das organizações: o poder no pensamento de Michel Foucault, com um olhar na universidade. Revista Triângulo, v. 8, n. 2, p. 185-194, 2015.

SILVA, G. F.; MACHADO JÚNIOR, S. D. S. A construção do sujeito em Michel Foucault. EntreLetras, v. 7, n. 1, p. 200-210, 2016.

SILVEIRA, R. A. Michel Foucault, poder e análise das organizações. Rio de Janeiro: FGV, 2005.

SKINNER, D. Foucault, subjectivity and ethics: towards a self-forming subject. Organization, v. 20, n. 6, p. 904-923, 2013.

SOCIO, L. As palavras e as coisas: uma história do pensamento que nos ajuda a entender a emergência da questão do sujeito na filosofia moderna. Sapere Aude: Revista de Filosofia, v. 7, n. 13, p. 58-69, 2016

SØRENSEN, B. M.; VILLADSEN, K. The naked manager: the ethical practice of an anti-establishment boss. Organization, v. 22, n. 2, p. 251-268, 2015.

SOUZA, W. L. Ensaio sobre a noção de poder em Michel Foucault. Múltiplas Leituras, v. 4, n. 2, p. 103-124, 2012.

SOUZA, E. M. et al. A analítica de Foucault e suas implicações nos estudos organizacionais sobre poder. Organizações \& Sociedade, v. 13, n. 36, p. $13-25,2006$

STARKEY, K.; HATCHUEL, A. The long detour: Foucault's history of desire and pleasure. Organization, v. 9, n. 4, p. 641-656, 2002.

TEDESCO, S. H.; RODRIGUES, C. A ética da metaestabilidade e a direção ética da clínica. Informática na Educação: Teoria \& Prática, v. 15, n. 1, p. 159-169, 2012.

THIRY-CHERQUES, H. R. À moda de Foucault: um exame das estratégias arqueológica e genealógica de investigação. Lua Nova, n. 81, p. 215 248,2010

VÄLIKANGAS, A.; SEECK, H. Exploring the Foucauldian interpretation of power and subject in organizations. Journal of Management \& Organization, v. 17, n. 6, p. 812-827, 2011.

VEIGA-NETO, A. Governo ou governamento. Currículo sem Fronteiras, v. 5 , n. 2, p. 79-85, 2005

VEIGA-NETO, A. Teoria e método em Michel Foucault (im)possibilidades. Cadernos de Educação, n. 34, p. 83-94, 2009. 
VILLADSEN, K. Tecnologia versus ação: uma falsa oposição atribuída a Foucault nos estudos organizacionais. Organizações \& Sociedade, v. 21, n. 71, p. 643-660, 2014.
WALTER, B. E. P.; WINKLER, C. A. G.; CRUBELLATE, J. M. O ideário taylorista, a gestão da subjetividade e o poder pastoral. Cadernos EBAPE.BR, Rio de Janeiro, v. 11, n. 1, p. 16-29, 2013. 